\title{
Sikos T. T., Tiner T. (szerk.) (2016): Tájak, régiók, települések, térben és időben. Tanulmánykötet Beluszky Pál 80. születésnapjára (Dialóg Campus Kiadó, Budapest, 479 o.)
}

\author{
BAJMÓCY PÉTER
}

\begin{abstract}
BAJMÓcY Péter: egyetemi docens, SZTE TTIK Gazdaság- és Társadalomföldrajz Tanszék; 6722 Szeged, Egyetem u. 2.; bajmocy@geo.u-szeged.hu; https://orcid.org/0000-0003$1692-4825$
\end{abstract}

Péter BAJMÓCY: associate professor, Department of Economic and Human Geography, Faculty of Science and Informatics, University of Szeged; Egyetem u. 2., H-6722 Szeged, Hungary; bajmocy@geo.u-szeged.hu; https://orcid.org/0000-0003-1692-4825

2016 decemberében Beluszky Pál, a magyar társadalomföldrajz egyik legnagyobb alakja betöltötte 80 . életévét. Az ünnepelt köszöntésére készült el e tanulmánykötet Sikos T. Tamás és Tiner Tibor szerkesztésében, melyben egykori és mai kollégái, fiatalok és idősebbek tisztelegnek előtte. Ebbe a kötetbe nem az ilyen esetekben gyakran előforduló, máshová nem publikálható maradékok vagy cikk formájába álcázott nyilvános köszöntések kerültek, hiszen a közölt 43 tanulmány legnagyobb része önmagában is értékes tudományos mü, a legtöbb nem marad el színvonalában a hazai folyóiratokban megjelenő tanulmányok átlagától. Mindezt a kötet megálmodói és szerkesztői azzal érték el, hogy gondosan megválogatták a szerzőket, Beluszky Pál egykori és mai munkatársai kerültek bele, elsősorban az MTA Csillagászati és Földtudományi Kutatóközpont Földrajztudományi Intézetéből és az MTA Közgazdaság- és Regionális Tudományi Kutatóközpont Regionális Kutatások Intézetéből, de más hazai és - egy német nyelvű tanulmány is megjelent a kötetben - osztrák-svájci műhelyekből is.

Beluszky Pál munkássága leginkább a településföldrajz részét képezi, azon belül alig van olyan részterület, amellyel ne foglalkozott volna. Az összes hazai településtípus megjelenik munkásságában Budapesttől a nagy-, közép- és kisvárosokon át a falvakig, az aprófalvakig, a tanyákig és a kertségekig. A településhálózat egyes elemeinek átalakulása mellett annak egészével is foglalkozik, a Kárpát-medence, Magyarország, az Alföld vonatkozásában, de áttekinti a városhálózat, a faluállomány vagy az alföldi városok fejlődésének, átalakulásának főbb tendenciáit, az ország településhálózati régióit, városaink vonzáskörzeteit is. Hajdú Zoltán $(2016,121$.) írja a kötetben megjelent tanulmányában, hogy „Beluszky Pál (...) az 1950-es évek közepétől tudatosan megélte a magyar falu

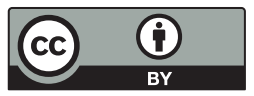


átalakulását, majd tudományos tevékenységében a szemtanú hitelességével érzékeny »híradója« lett e folyamatnak". Beluszky munkássága nemcsak a településállomány minden egyes típusára terjedt ki, de területileg sincs olyan csücske az országnak, amellyel legalább egy tanulmánya ne foglalkozott volna, így bejárta az Alföldet, az Őrséget, a Cserehátot, Szatmárt, a Közép-Tisza-vidéket és a budapesti agglomerációt. Mindezt azért is megtehette, mert pályafutása számos állomáshoz kötötte, amelynek Szolnok, Piszke, Tiszafüred, Berettyóújfalu, Budapest vagy Gödöllő talán a legfontosabb helyszínei. Beluszky számos téren összegezte a hazai településföldrajz eredményeit, s e szintetizáló munkái tekinthetők a legnagyobb hatásúaknak.

Tudományos munkásságának második legfőbb csoportját a történeti földrajzi munkák adják, melyek fókuszpontjában a dualizmus korának hazai társadalmi-gazdasági-területi átalakulási folyamatai állnak, de munkássága kiterjed a középkorra vagy a 20. század második felének hazai folyamataira is. Kiemelt szerepet kap történeti földrajzi kutatásaiban az Alföld, az alföldi út, az Alföld másságának megismerése, annak okainak feltárása. Harmadrészt Beluszky Pál néhány tanulmányában a tudományosság elméleti kérdéseivel, ezen beül a társadalomföldrajz helyzetével és aktuális problémáival foglalkozik. Számos módszertani újítást vezetett be Magyarországon. Munkássága legnagyobb értékének mégis azt tartom, hogy úgy tudott szintetizáló, az ország településhálózatának egészét elemző munkákat alkotni, hogy eközben a hálózat egyes elemeiről is alapos képe van, olyan kutató, aki képes újat mondani a faluállomány átalakulásának fó tendenciáiról, de közben szinte bármelyik hazai faluról is. Sajnos a hazai társadalomföldrajzban ez igencsak ritka.

A kötetben a néhány oldalas „rendhagyó előszó” után 43 tanulmányt találunk, melyek összterjedelme 471 oldal. A tanulmányok a szerzők neveinek ábécésorrendje alapján következnek, így a hasonló témájú tanulmányok a kötet különböző részeiben találhatók. Mivel azonban tematikailag nagyon széles spektrumot ölelnek fel a kötetben publikált írások, így nehéz is lett volna tematikusan csoportosítani őket. Mindenképp ki kell emelni, hogy - szemben sok tiszteletkötettel - itt 10-12 oldal közlésére volt lehetőségük a szerzőknek, s ez mindenképp a tartalom javára szolgált. A kötet legtöbb munkája önálló, értékes tudományos mü, korrekt szakirodalmi áttekintéssel.

Az ilyen jellegű kötetekben szokásos, hogy a szerzők kapcsolatot próbálnak keresni a saját tudományos tevékenység és az ünnepelt által kutatott témák között. Itt is hasonló volt a helyzet, s mivel Beluszky életműve szerteágazó, ez nem bizonyult lehetetlennek. Számos esetben a kutatási témák összekapcsolódnak, ezek talán a kötet legszínvonalasabb tanulmányai. Másoknál már nehezebb volt megtalálni a közös pontot, sok esetben ez „és ezzel majdnem foglakozott egyszer Beluszky is" típusú kapcsolat lett, egyébként komoly tudományos értékkel bíró tanulmányoknál. A harmadik csoportba olyan szerzők tartoznak, akik nem foglalkoztak hasonló témákkal, de próbáltak hozzászólni a településhálózat kérdéseihez vagy az ünnepelt által kutatott témákhoz - ezek a próbál- 
kozások nem a kötet legerősebb tanulmányai. Végül több szerző nem keresett vagy nem talált közös pontokat, ők a saját témájukkal köszöntötték Beluszky Pált, az ünnepeltre való utalás vagy hivatkozás nélkül. A 43 tanulmányban összesen 95 független hivatkozás van Beluszky Pál műveire, mutatva az ünnepelt széles körű szakmai tevékenységét. A 43 tanulmányból egy német nyelven íródott (Doris Wastl-Walter munkája), a többi magyarul, és a tudományosság szempontjából két kakukktojás szerepel a kötetben. Kocsis Károly szerzőtársaival a Magyarország Nemzeti Atlaszának legújabb kiadása szerkesztésének kulisszatitkaiba avat be bennünket, mely térképlapjainak munkálataiban egyébként az ünnepelt is részt vesz, Csatári Bálint pedig a „hőskorban” Beluszkyval töltött kubai tanulmányút élményeit meséli el a maga humoros stílusában.

A tanulmánykötet szakmai oldaláról nehéz átfogó képet adni, hiszen tematikailag rendkívül változatos, ugyanakkor ez adja egyik legnagyobb értékét is, hiszen a társadalomföldrajz legtöbb részterületének művelője talál benne a maga számára hasznos és érdekes tanulmányokat. Talán a legtöbb mű az Alföld átalakulásával, településhálózatával és ezen belül a tanyarendszerrel foglalkozik. Baranyi Béla az „alföldi út” kérdéséhez tesz hozzá újabb adalékokat, Becsei József, Romvári Róbert és a Nagy Gábor - Dudás Gábor szerzőpáros a tanyákról értekezik, Lennert József a Beluszky Pál és Sikos T. Tamás által is többször használt faktor- és klaszteranalízis módszerével tipizálja a dél-alföldi településeket, Jankó Ferenc és Győri Róbert pedig az Alföld természetátalakításáról ír.

A második csomópontot a kistelepülések és a periferikus térségek jelentik. Ide kapcsolódik G. Fekete Éva Bogácsról, Nagyné Molnár Melinda Pázmándról, Székely Kinga Katalinnak a Csíki-medence falvairól szóló tanulmánya, Kiss Éva munkája a Közép-Tisza-vidékről, Nagy Erika cikke a sarkadi kistérségről a társadalmi marginalizáció vonatkozásában. Ebbe a körbe sorolható Timár Judit részben elméleti munkája a falusi társadalomról, valamint Kovács Katalin és Tóth Tamás átfogó munkái a kistelepülések, az aprófalvak helyzetéről és gazdaságfejlesztési lehetőségeiről.

A harmadik tematikus csoportot a történeti földrajzi és gazdaságtörténeti munkák adják, ide tartoznak a kisebb léptékű művek közül Frisnyák Sándor Bodrogszerdahelyről vagy Kókai Sándor Szeged vonzáskörzetéről írt tanulmányai, a nagyobb léptékủ munkák közül pedig Gál Zoltánnak a bankrendszer fejlődéséről vagy Rácz Lajosnak a klímamigrációról közölt művei. A nagyvárosok társadalomföldrajzi kérdései adnak egy kisebb blokkot, ide elsősorban Budapesttel kapcsolatos tanulmányok tartoznak, így Kovács Zoltán és Egedy Tamás cikke a metropolizációról, Michalkó Gábor és szerzőtársainak munkája a budapesti agglomeráció szatellitturizmusáról vagy Sikos T. Tamás tanulmánya a föváros kiskereskedelméről, de a vidéki nagyvárosok is megjelennek (Rechnitzer János: Győr, Kókai Sándor: Szeged). Elméleti kérdéseket elsősorban Berényi István, Nemes Nagy József és Timár Judit írásai feszegetnek. A kötetben emellett - a teljesség igénye nélkül - előkerülnek a terület- és településfejlesztés, a közigazgatási földrajz, a kereskedelem és a távközlés földrajza, a közlekedésföldrajz, a kultu- 
rális földrajz, a turizmusföldrajz, a szocialista városok, a településmenedzsment, a katonai földrajz, a globális migráció és a határmentiség kérdései is.

A tanulmánykötet látlelet is a hazai társadalomföldrajz jelenlegi állapotáról. Az előbbiek következtében a tudományterület problémái kevéssé jelennek meg e kötetben, azonban érdemes olyan szemmel olvasni a tanulmányokat, hogy egyrészt mi a receptje az átlagost messze meghaladó színvonalú tanulmánykötet összeállításának (mind tartalomban, mind kivitelben). Másrészt pedig hogy melyek a hazai társadalomföldrajz problémáinak a sorok közé be-beszüremkedő jelei (hivatkozási kultúra, az egyedi és az általános szélsőséges elválása, tévkövetkeztetések, a helyismeret, a helyi viszonyok ismeretének hiánya, a néha nem adekvát ábrák stb.).

Mindennek ellenére egy igen jó színvonalú tiszteletkötetet foghat a kezébe az olvasó, ami nagyban köszönhető az ünnepeltnek, Beluszky Pálnak, személyiségének és munkásságának; ahogyan Nemes Nagy József $(2016,315$.$) nevezi tanul-$ mányában, a „legmodernebb konzervatívnak” a hazai társadalomföldrajzban. Számos vonatkozásban ő jelenti a kapcsot a konzervatívak és a modernek között, mindkét csoport számára inspirálók a művei. Beluszkyt a maga különleges, szépirodalmi igényü stílusában idézve „az lenne kívánatos, amit nyilvánvalóan elérni nem lehet, ha sikerülne a társadalmi folyamatok térbeli vonatkozásait, annak feltételeit, indítóokait, következményeit, s a teljes kapcsolathálót minden vonatkozásban kibontani” (Rácz, Beluszky 2003, 5.).

\section{Irodalom}

Hajdú Z. (2016): Településfejlesztési minta, avagy „koraszülött, megtagadott siker?” In: Sikos T. T., Tiner T. (szerk.): Tájak, régiók, települések térben és idóben. Tanulmánykötet Beluszky Pál 80. születésnapjára. Dialóg Campus Kiadó, Budapest, 121-130.

Nemes, Nagy J. (2016): A hely arca és számai. In: Sikos T. T., Tiner T. (szerk.): Tájak, régiók, települések térben és időben. Tanulmánykötet Beluszky Pál 80. születésnapjára. Dialóg Campus Kiadó, Budapest, 315-321.

Rácz L., Beluszky P. (2003): „...többnyire azt mondom, geográfus vagyok.” Interjú Beluszky Pállal. Korall, 14., 5-28. 